\title{
Inhibition of cytokine gene expression and induction of chemokine genes in non-lymphatic cells infected with SARS coronavirus Martin Spiegel and Friedemann Weber*
}

\author{
Address: Abteilung Virologie, Institut für Medizinische Mikrobiologie und Hygiene, Universität, Freiburg, D-79008 Freiburg, Germany \\ Email: Martin Spiegel - martin.spiegel@uniklinik-freiburg.de; Friedemann Weber* - friedemann.weber@uniklinik-freiburg.de \\ * Corresponding author
}

Published: 29 March 2006

Virology Journal2006, 3:17 doi:10.1186/1743-422X-3-17

This article is available from: http://www.virologyj.com/content/3/1/17

(C) 2006Spiegel and Weber; licensee BioMed Central Ltd.

This is an Open Access article distributed under the terms of the Creative Commons Attribution License (http://creativecommons.org/licenses/by/2.0), which permits unrestricted use, distribution, and reproduction in any medium, provided the original work is properly cited.
Received: 28 October 2005

Accepted: 29 March 2006

\begin{abstract}
Background: SARS coronavirus (SARS-CoV) is the etiologic agent of the severe acute respiratory syndrome. SARS-CoV mainly infects tissues of non-lymphatic origin, and the cytokine profile of those cells can determine the course of disease. Here, we investigated the cytokine response of two human non-lymphatic cell lines, Caco-2 and HEK 293, which are fully permissive for SARSCoV.

Results: A comparison with established cytokine-inducing viruses revealed that SARS-CoV only weakly triggered a cytokine response. In particular, SARS-CoV did not activate significant transcription of the interferons IFN- $\alpha$, IFN- $\beta$, IFN- $\lambda$ I, IFN- $\lambda 2 / 3$, as well as of the interferoninduced antiviral genes ISG56 and MxA, the chemokine RANTES and the interleukine IL-6. Interestingly, however, SARS-CoV strongly induced the chemokines IP-I0 and IL-8 in the colon carcinoma cell line Caco-2, but not in the embryonic kidney cell line 293.

Conclusion: Our data indicate that SARS-CoV suppresses the antiviral cytokine system of nonimmune cells to a large extent, thus buying time for dissemination in the host. However, synthesis of IP-I0 and IL-8, which are established markers for acute-stage SARS, escapes the virus-induced silencing at least in some cell types. Therefore, the progressive infiltration of immune cells into the infected lungs observed in SARS patients could be due to the production of these chemokines by the infected tissue cells.
\end{abstract}

\section{Background}

For most viruses, the initial encounter with the host takes place in cells of non-lymphatic origin. The outcome of this primary infection can determine the course of disease, and the cytokine response of the infected cell plays a vital part. Type I interferons (IFN- $\alpha / \beta)$ are potent, antivirally active cytokines which can be produced by most, if not all, body cells in response to virus infection. IFNs not only trigger the synthesis of antivirally active proteins, they also activate the innate immune system and help to shape adaptive immunity [1]. Other virus-induced cytokines and chemokines activate the adaptive immune system and direct the migration of leukocytes [2]. Viruses, on the other hand, have evolved various mechanisms to counteract the host's cytokine response [3], and their ability to induce or inhibit cytokine production in infected cells has direct consequences for the balance between host defense and virus propagation.

SARS coronavirus (SARS-CoV) is the etiologic agent of severe acute respiratory syndrome (SARS), a life-threatening new human disease which recently emerged in China 


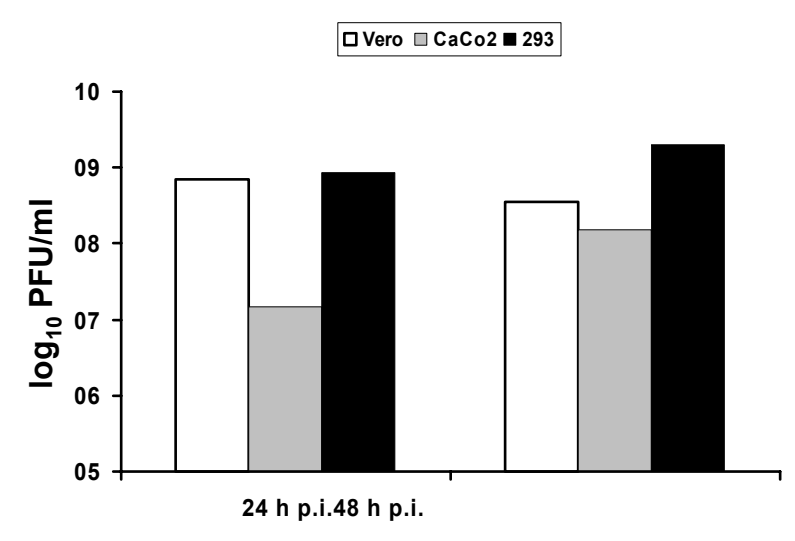

Figure I

Virus titers. Simian Vero cells (white bars), human Caco-2 cells (grey bars), and human low-passage HEK 293 cells (black bars) were infected at a multiplicity of infection (MOI) of 5 infectious particles per cell. Virus titers in the supernatants were determined $24 \mathrm{~h}$ post-infection and $48 \mathrm{~h}$ postinfection by plaque assays.

[4-7]. Characteristic SARS symptoms are high fever, myalgia, dry cough and lymphopenia, and in around 30\% of cases patients also developed an atypical form of pneumonia [8].

The mechanisms underlying SARS-CoV-mediated pathogenesis remain largely unexplained. Autopsies from deceased patients revealed severe damage of the lungs and lymphatic tissues, accompanied by infiltrations of monocytic cells [9-11]. This may indicate that immunopathogenesis is involved in the severe outcome of the disease, providing the rationale for SARS therapy with immunosuppressant corticosteroids [12]. On the other hand, there is evidence that cell damages could be directly caused by the virus, since SARS-CoV is cytolytic [13] and capable to systemically infect human hosts [14-16]. In addition, virus particles and signs of necrosis were found in affected tissues [11], and high viral loads are predictive of adverse clinical outcome [17]. Interestingly, however, the acute lung injuries and respiratory failure observed in severe cases occured while viral loads were declining [16], again favouring the hypothesis of immune-mediated lung damage.

Virus-induced cytokines not only play a significant role in host defense, but also in immunopathogenesis. Investigations of the cytokine profiles of SARS patients have shown that the proinflammatory cytokines and chemokines IL-6, IL-8 and IP-10 (CXCL10) are strongly upregulated [1823]. Cell culture studies, by contrast, did not reveal a clear picture of SARS-CoV-induced cytokines. In some cases both IL-8 and IP-10 were upregulated [24], whereas in other cases either only IL-8 [25,26], only IP-10 [27], or no cytokines were induced at all [28]. IL-6 was only moderately upregulated [29], or not detected at all [24-26]. Thus, it is still unclear whether the cytokine storm in SARS patients was directly caused by the virus, i.e. produced by SARS-CoV-infected cells, or whether it is a secondary effect, i.e. the result of strong activation of the immune system.

With one notable exception [24], most studies investigating the cellular cytokine response to SARS-CoV were either based on immune cells [25,27-29] or on Huh7 hepatoma cells inoculated with unphysiologically high amounts of virus [26]. Thus, the overall picture of the cytokine response of non-immune cells, which are most probably the prime targets of SARS-CoV, may still be incomplete. To learn more about it, a human cell line would be needed which, on one hand, can support the complete viral replication cycle, but on the other hand is also able to produce cytokines which are potentially antiviral. However, most cell lines which are permissive for SARS-CoV have lost the ability to synthesize IFNs, the most potent antiviral cytokines [24,30,31]. In this study, we identified an IFN-competent human embryonic kidney (HEK) 293 cell clone which supports the growth of SARS-CoV. Using these cells as well as the established human colon carcinoma cell line Caco-2 [24,31], we investigated the SARS-CoV-induced production of representative cytokines, chemokines and antiviral genes. Our studies revealed that SARS-CoV is capable to suppress the antiviral cytokine response of infected cells to a large extent. Interestingly, however, induction of the chemokines IP-10 and IL-8 escaped suppression by SARS-CoV in Caco- 2 cells, but not in HEK 293s. Thus, SARS-CoV efficiently blocks the innate host cell defense at a very early step of infection, buying time to colonize the host. With the possible exception of IP-10 and IL-8, most cytokines detected in SARS patients may therefore be produced by the infiltrating immune cells, and not by the resident tissue cells. These data may help to explain both the rapid rise in virus titers during the initial stage of disease, caused by the suppression of antiviral cytokines, as well as the progressive infiltration of immune cells into the infected lungs, which could be due to the production of chemokines by the infected tissue cells.

\section{Results}

\section{Growth of SARS-CoV in different cell lines}

Vero cells, which are standard for growth of SARS-CoV $[30,31]$, lack type I IFN genes [32,33] and therefore are not suitable for cytokine analyses. In search of an appropriate in vitro system, we tested several IFN-competent human cell lines for SARS-CoV growth and identified a low-passage clone of HEK 293 cells [34] as being fully per- 


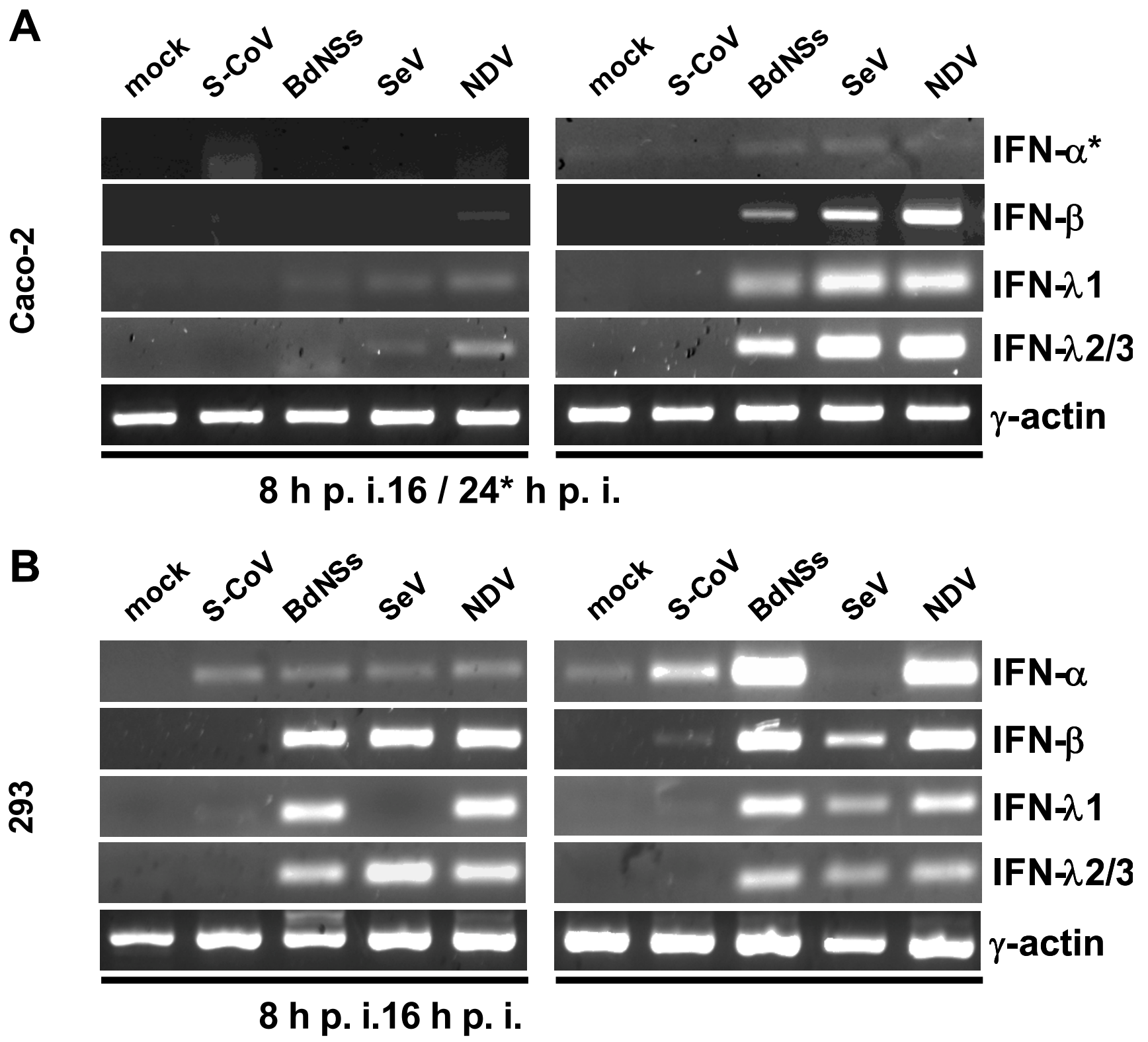

Figure 2

Interferon production by virus-infected human cells. Caco-2 cells (A) and HEK 293 cells (B) were infected with SARSCoV or the IFN-inducing control viruses Bunyamwera deINSs (BdeINSs), Sendai virus (SeV), Newcastle disease virus (NDV), or were left uninfected (mock). At $8 \mathrm{~h}$ (left panels) or at $16 \mathrm{~h}$ (right panels) post-infection, total RNA was isolated and investigated by RT-PCR for the presence of different IFN mRNAs. The cellular $\gamma$-actin mRNA served as loading control. Note that for the reliable detection of IFN- $\alpha$ in Caco- 2 cells (A, upper right panel) the infection time had to be extended to $24 \mathrm{~h}$.

missive. Fig. 1 shows that titers of HEK 293 cells and Vero cells were comparable and rather high already at $24 \mathrm{~h}$ post-infection. Caco- 2 cells, by contrast, produce approximately 100-fold less virus at $24 \mathrm{~h}$ post-infection, and 10fold less at $48 \mathrm{~h}$ post-infection (Fig. 1). Thus, we considered both the Caco- 2 cells and the low passage HEK 293 cells as useful systems for studying the influence of SARS-
$\mathrm{CoV}$ on the immune system-independent induction of cytokines.

\section{Interferon genes and their antiviral effectors}

To properly assess the cytokine profile of SARS-CoV infection, we compared it with well-characterized cytokine inducers such as Bunyamwera delNSs virus (BdNSs [35]), 


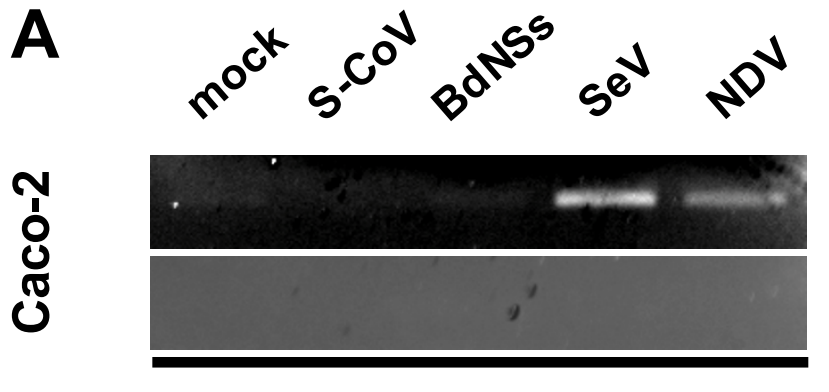

8 h p. i.

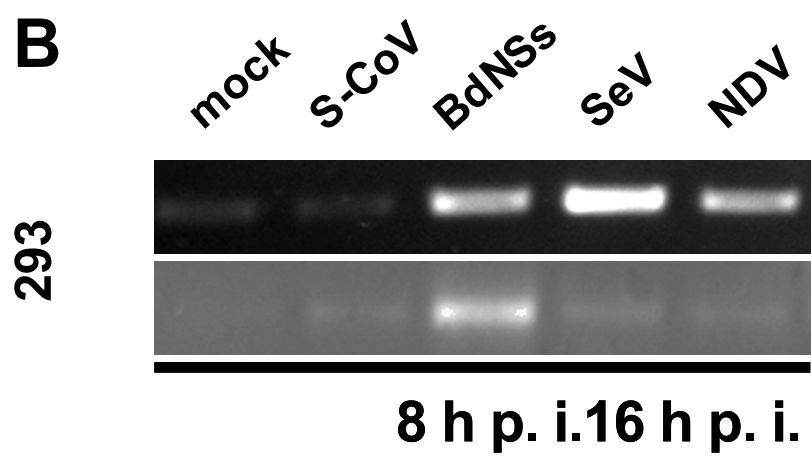

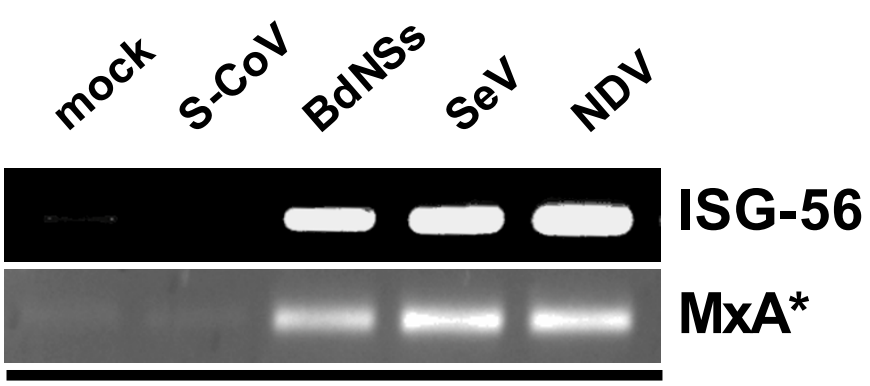

$16 / 24^{*}$ h p. i.

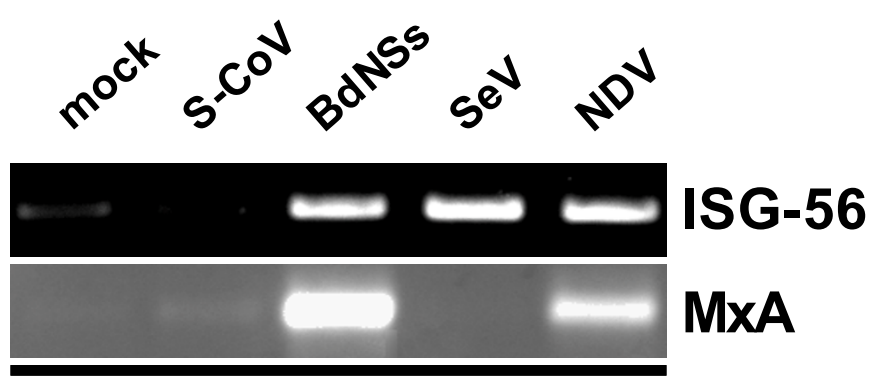

Figure 3

Interferon-stimulated genes. RNA samples of Caco-2 cells (A) and HEK 293 cells (B) described in Fig. 2 were investigated by RT-PCR for the presence of ISG56 and MxA mRNAs. As for IFN- $\alpha$ (see Fig. 2A), for detection of MxA mRNA in Caco-2 cells an extended infection period of $24 \mathrm{~h}$ was necessary (A, lower right panel).

Sendai virus (SeV) and Newcastle disease virus (NDV). In addition, we deemed it necessary to monitor cytokine synthesis both at $8 \mathrm{~h}$ and at $16 \mathrm{~h}$ post-infection, since we previously found a striking difference between the early and the late host cell response to SARS-CoV [36].

The first set of tested cytokines comprised the classical antiviral cytokines IFN- $\alpha$ and IFN- $\beta[1]$, and the novel interferons IFN- $\lambda 1$ and IFN- $\lambda 2 / 3$ [37]. To test their induction in cell culture, we infected with 5 plaque-forming units (pfu) of viruses per cell, and analyzed cytokine mRNAs by RT-PCR. As it is shown in (Fig. 2A and 2B), clear signals for all IFNs were detected after infection with the control viruses BdNSs, SeV and NDV. For SARS-CoV, by contrast, only a weak signal for IFN- $\alpha$ was detected in HEK 293 cells, and none for IFN- $\beta$ or the IFN- $\lambda$ s in either cell line. All preparations contained similar amounts of input RNA, since the $\gamma$-actin control mRNA was present in equal amounts (Fig. 2A and 2B, lower panels). It was of interest to see whether virus infection would lead to the upregulation of antiviral, IFN-stimulated genes (ISGs). As specific and sensitive markers we used the ISG56 gene which is induced both by IFNs and by virus infection $[38,39]$ and the MxA gene which is exclusively activated by IFNs [40]. As is evident from Fig. 3, no significant ISG induction occurs for SARS-CoV, whereas the control viruses activated ISG expression. Note that $\mathrm{SeV}$ blocks in HEK 293 cells the synthesis of IFN- $\alpha$ (see Fig. 2B, upper right panel) and of MxA (Fig. 3B, lower right panel), most probably because of its ability to inhibit IFN-induced signaling [41]. Curiously, this does not happen in Caco-2 cells (Fig. 3A, lower right panel), suggesting cell type-specific differences in cytokine signaling.

Taken together, these data demonstrate that, in contrast to the other viruses tested, SARS-CoV suppresses the activation of the antiviral IFNs and the IFN-induced effector genes to a large extent.

\section{Induction of chemokines by infected cells}

IP-10 and RANTES are potent chemoattractants for activated T cells and NK cells [2]. When we infected Caco-2 

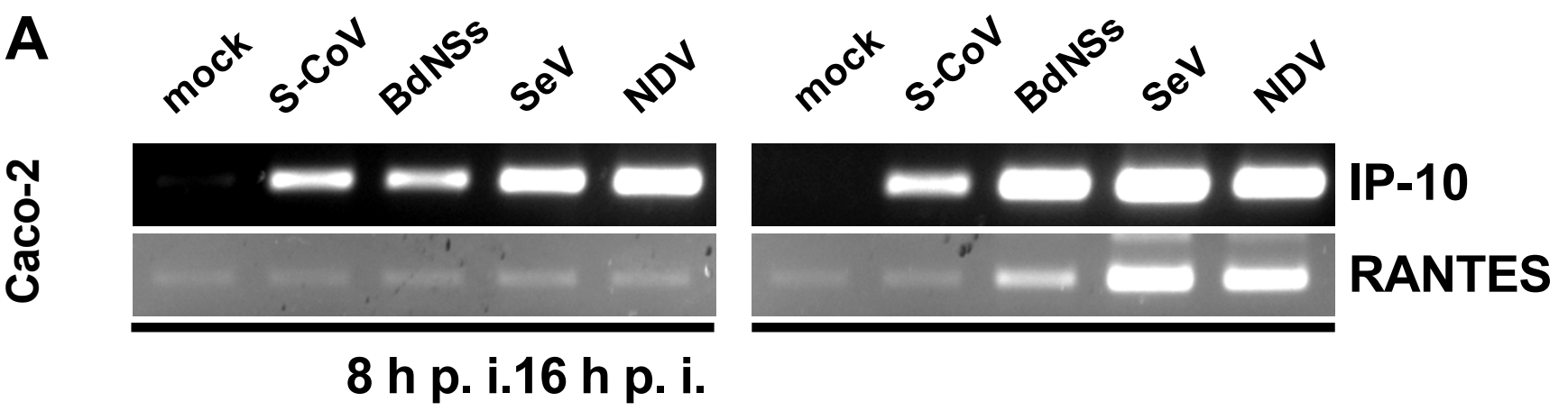

B
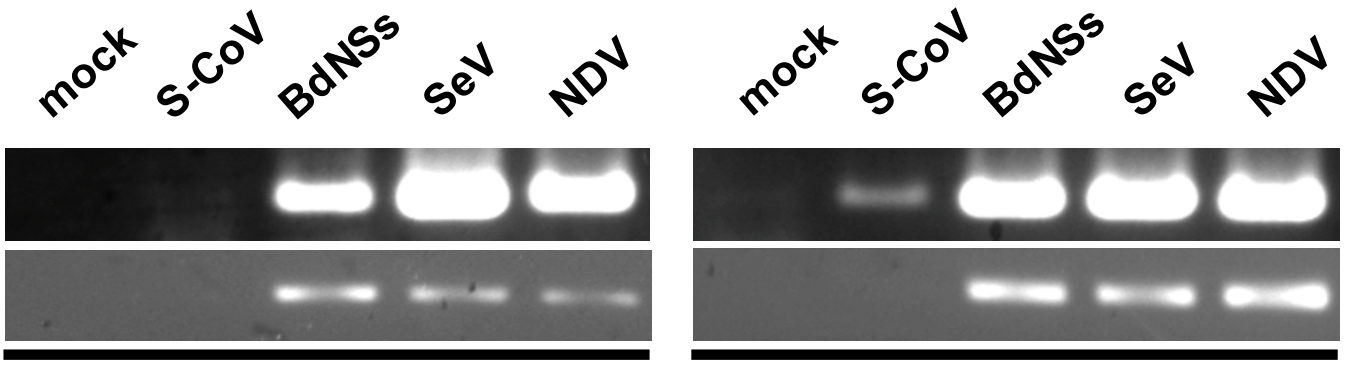

IP-10
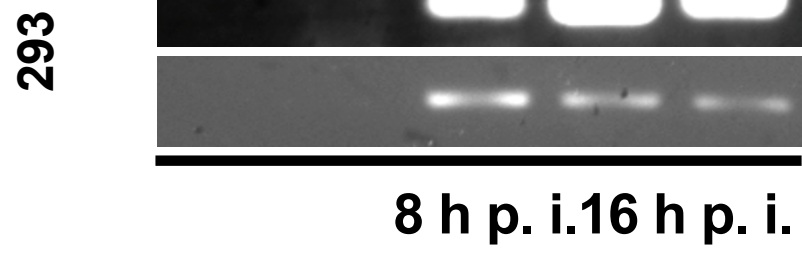

RANTES

\section{Figure 4}

Chemokine production. RNA samples of Caco- 2 cells (A) and HEK 293 cells (B) described in Fig. 2 were assayed by RTPCR for IP-IO and RANTES mRNA levels.

cells, significant amounts of IP-10 mRNA were synthesized (Fig. 4A, upper panels). This strong upregulation occurred independently of the virus, suggesting a general response to virus infection. Although IP-10 mRNA levels induced at $16 \mathrm{~h}$ p.i. by SARS-CoV are slightly lower than by the other viruses, our data are in good agreement with previous studies $[24,27]$. Induction of RANTES, by contrast, was restricted to the cytokine-inducing viruses, whereas infection with SARS-CoV had no effect above background levels (Fig. 4A, lower panels). We then tested HEK 293 cells in a similar way. Much to our surprise, IP10 mRNA was not detectable early after infection with SARS-CoV (Fig. 4B, upper left panel), and only very weakly expressed after longer infection (Fig. 4B, upper right panel).

RANTES mRNA again was not detectable for SARS-CoV (Fig. 4B, lower panels). All three cytokine-inducing viruses activated IP-10 and RANTES expression in HEK 293 cells as expected (Fig. 4B, upper and lower panels).

Thus, SARS-CoV induces IP-10 gene expression in Caco-2 cells, but not in HEK 293 cells, again suggesting that the cytokine response is dependent on the host cell type. RANTES expression, by contrast, is never induced by SARS-CoV, although the cells respond normally to other viruses.

\section{Induction of IL-6 and IL-8}

The proinflammatory cytokine IL- 6 and the chemokine IL-8 are strongly upregulated in SARS patients $[18,19]$, but from cell culture studies no clear picture emerged [24$26,29]$. We investigated IL- 6 and IL-8 production by Caco2 and HEK 293 cells infected with SARS-CoV and compared it with the other RNA viruses. As shown in Fig. 5, IL6 is induced only weakly by SARS-CoV, independent of the cell line used (Fig. 5A and 5B, upper panels). IL-8, by contrast, is clearly induced by SARS-CoV in Caco-2 cells, but not in HEK 293 cells (Fig. 5A and 5B, lower panels). The control viruses invariably induced both IL- 6 and IL-8, demonstrating that the cell lines are capable to produce these cytokines.

Thus, SARS-CoV strongly induces IL-8, but not IL- 6 in a cell-type dependent manner. This may suggest that the IL8 detected in SARS patients $[18,19]$ is directly synthesized 
A
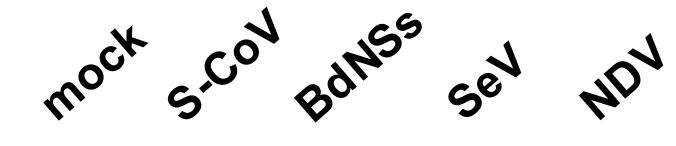

1
0
0
0

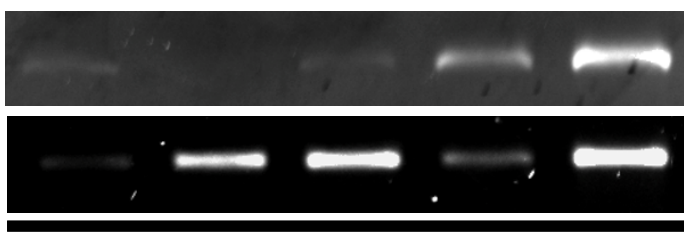

8 h p. i.16 h p. i.
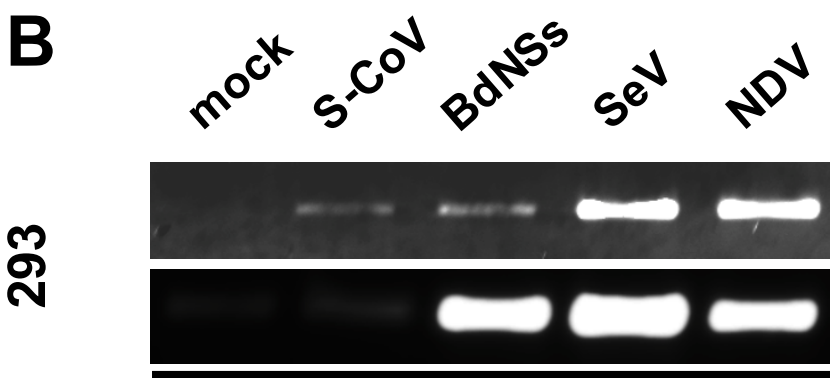

\section{8 h p. i.16 h p. i.}
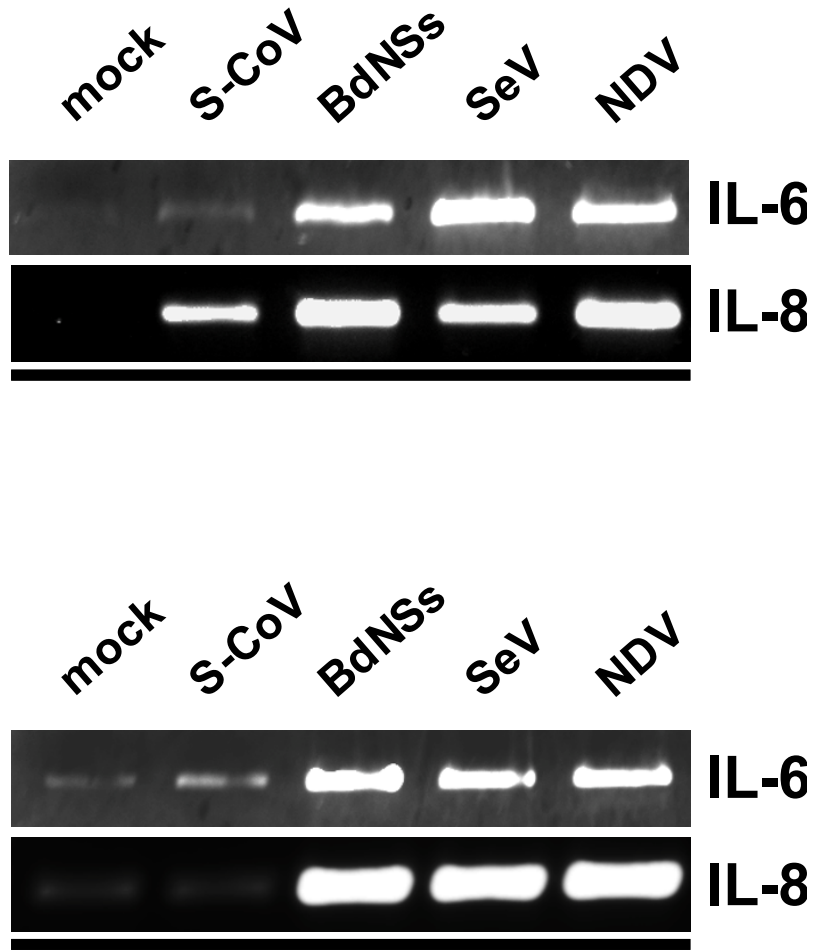

\section{Figure 5}

Interleukin production. RNA samples of Caco-2 cells (A) and HEK 293 cells (B) described in Fig. 2 were investigated by RTPCR for the presence of IL-6 and IL-8 mRNAs.

by infected resident cells, whereas IL-6 is more likely a secondary response mediated by infiltrating immune cells.

Taken together, our data demonstrate that SARS-CoV in general is a weak inducer of cytokines and antiviral genes in non-lymphatic cells. Chemokines like IP-10 and IL-8, however, can be directly upregulated in SARS-CoV in a cell-type-dependent manner.

\section{Discussion}

The activation of immune-relevant cytokines and host cell genes by SARS-CoV in cells and patients was the subject of several previous investigations [18,21,22,24-29,42-44]. However, most of the cell culture studies were either based on immune cells which do not represent the majority of infected cells [25,27-29], or on Huh7 hepatoma cells which needed to be infected with 100 pfu per cell, i.e. with unphysiologically high amounts of virus [26]. Moreover, Huh7 cells are known to be deficient in the antiviral cytokine response [45]. Thus, it was not entirely clear whether the patients' cytokine response was caused by virus-infected cells, or whether it was mediated by the activated immune system. Furthermore, it was not systematically investigated how the cytokine induction by SARS$\mathrm{CoV}$ compares to other viruses. Here, we have used three control viruses and two different cells lines to elucidate and compare the induction of cytokines by SARS-CoV. Our results demonstrate that SARS-CoV does not induce significant amounts of IFNs, antiviral genes, RANTES, and IL-6. In agreement with this finding, SARS-CoV-infected macrophages and dendritic cells lack IFN induction $[27,29]$. IP-10 and IL-8, however, can be activated by SARS-CoV. This suggests that these chemokines, which are reliable markers of acute-stage SARS $[18,20,21,23]$, are not only produced in response to IFN- $\gamma$ after activation of the immune system as suggested, but may also be directly secreted by infected tissue cells. An upregulation of either IP-10 and/or IL-8 was observed in several studies using SARS-CoV-infected Caco-2 cells [24], macrophages [27], peripheral blood mononuclear cells [25], and dendritic cells [29]. Using HEK 293 cells, by contrast, we found that SARS-CoV is able to downregulate also IP- 10 and IL-8 pro- 
duction. Similarly, recent studies showed that peripheral blood monocytes from SARS patients do not produce any cytokines [28]. Thus, chemokine induction by SARS-CoV appears to be highly cell type-specific.

With the exception of IP-10 and IL- 8 , SARS-CoV is capable to suppress the production of a wide range of cytokines. This is in agreement with our previous finding that SARS$\mathrm{CoV}$ inhibits the crucial cytokine transcription factor IRF3 [36], providing a possible mechanism for the high potential of this pathogen to suppress the host response. Of note, SARS-CoV is highly sensitive to the antiviral action of IFNs both in vivo and in vitro [46-51], thus explaining why the virus needs to suppress IFN induction in advance.

\section{Conclusion}

In the initial phase of SARS, the virus grows exponentially and spreads to different organs, including the lungs $[8,14]$. Our data may explain this rapid and efficient dissemination of SARS-CoV. By slowing down expression of IFNs and their antiviral genes in the infected tissue cells, the virus buys time during the initial, critical phase of infection in order to grow unhindered in the host. At the same time, however, the virus-induced chemokines IP-10 and IL-8 attract immune cells. Possibly, this mixture of high-level virus replication followed by the invasion of activated immune cells results in a strong inflammatory response, leading to a cytokine storm and the severe and potentially fatal respiratory distress which is the hallmark of full-blown SARS.

\section{Methods \\ Cells and viruses}

Simian VeroE6 cells, human Caco-2 cells and human embryonic kidney (HEK) 293 cells were maintained and grown as described $[24,36]$. The low-passage HEK 293 cell clone [34] was purchased from Microbix Biosystems, Toronto, Canada. All experiments were performed with HEK 293 cells between passage 38 and 48. The FFM-1 isolate of SARS-CoV was kindly provided by Stephan Becker, University of Marburg, Germany. Bunyamwera delNSs virus [35], Sendai virus and Newcastle disease virus were used as controls.

\section{Plaque assays}

Virus plaque assays were performed as described previously [50]. Briefly, Vero cell monolayers were infected with dilutions of supernatants from infected cells, overlaid with soft agar, and allowed to form plaques for $72 \mathrm{~h}$. Then the agar overlay was removed and cells were stained with a solution of $1 \%$ crystal violet, $3,6 \%$ formaldehyde, $1 \%$ methanol, and $20 \%$ ethanol.

\section{RT-PCR analyses}

Cells were infected for the indicated times, total RNA was extracted and treated with DNase I. For reverse transcription (RT), $1 \mu \mathrm{g}$ of RNA was incubated with $200 \mathrm{U}$ of Superscript II reverse transcriptase (Invitrogen) and 100 ng random hexanucleotides in $20 \mu \mathrm{l}$ of $1 \times \mathrm{RT}$ buffer (Invitrogen) supplied with $1 \mathrm{mM}$ each of the four deoxynucleotide triphosphates, $20 \mathrm{U}$ of RNasin, and $10 \mathrm{mM}$ dithiothreitol. The resulting cDNA was amplified by 35 cycles of PCR, with each cycle consisting of $30 \mathrm{sec}$ at $94^{\circ} \mathrm{C}$, $1 \mathrm{~min}$ at $58^{\circ} \mathrm{C}$ (using primer pairs specific for IP-10, IL-6, IL- 8 and RANTES) or at $56^{\circ} \mathrm{C}$ (all other primer pairs), and $1 \mathrm{~min}$ at $72^{\circ} \mathrm{C}$, followed by $10 \mathrm{~min}$ at $72^{\circ} \mathrm{C}$. Primer sequences are available from the authors upon request.

\section{List of abbreviations}

BdNSs, Bunyamwera delNSs virus; HEK, human embryonic kidney; IFN, interferon; IL, interleukine; ISG, interferon-stimulated gene; NDV, Newcastle disease virus; RANTES, Regulated on activation, normal $\mathrm{T}$ cell expressed and secreted; SARS-CoV, SARS coronavirus; SeV, Sendai virus

\section{Competing interests}

The author(s) declare that they have no competing interests.

\section{Authors' contributions}

MS carried out the virus growth studies and the RT-PCR analyses, participated in the design of the study, and has given final approval of the version to be published. FW carried out virus infections, participated in the design of the study, and was responsible for drafting and finalizing the manuscript. All authors read and approved the final manuscript.

\section{Acknowledgements}

We thank Otto Haller for support and helpful comments, and Martin Michaelis and Peter Staeheli for critically reading the manuscript. This work was supported by grants from the Deutsche Forschungsgemeinschaft (grant We 2616/4) and the Sino-German Center for Research promotion (grant GZ Nr. 239 (202/I2)).

\section{References}

I. Samuel CE: Antiviral actions of interferons. Clin Microbiol Rev 200I, 4:778-809.

2. Rollins BJ: Chemokines. Blood 1997, 90:909-28.

3. Weber F, Kochs G, Haller O: Inverse interference: how viruses fight the interferon system. Viral Immunol 2004, I 7:498-5 I5.

4. Drosten C, Gunther S, Preiser W, van der Werf S, Brodt HR, Becker S, Rabenau H, Panning M, Kolesnikova L, Fouchier RA, et al.: Identification of a novel coronavirus in patients with severe acute respiratory syndrome. N Engl J Med 2003, 348: I967-76.

5. Peiris JS, Lai ST, Poon LL, Guan Y, Yam LY, Lim W, Nicholls J, Yee WK, Yan WW, Cheung MT, et al.: Coronavirus as a possible cause of severe acute respiratory syndrome. Lancet 2003, 36 I:1319-25.

6. Ksiazek TG, Erdman D, Goldsmith CS, Zaki SR, Peret T, Emery S, Tong S, Urbani C, Comer JA, Lim W, et al.: A novel coronavirus associated with severe acute respiratory syndrome. $N$ EnglJ Med 2003, 348: 1953-66. 
7. Kuiken T, Fouchier RA, Schutten M, Rimmelzwaan GF, van Amerongen G, van Riel D, Laman JD, de Jong T, van Doornum G, Lim $W$, et al.: Newly discovered coronavirus as the primary cause of severe acute respiratory syndrome. Lancet 2003, 362:263-70

8. Peiris JS, Guan Y, Yuen KY: Severe acute respiratory syndrome. Nat Med 2004, 10:S88-97.

9. Ding Y, Wang H, Shen H, Li Z, Geng J, Han H, Cai J, Li X, Kang W, Weng $\mathrm{D}$, et al.: The clinical pathology of severe acute respiratory syndrome (SARS): a report from China. J Pathol 2003, 200:282-9.

10. Lang ZW, Zhang LJ, Zhang SJ, Meng X, Li JQ, Song CZ, Sun L, Zhou YS, Dwyer DE: A clinicopathological study of three cases of severe acute respiratory syndrome (SARS). Pathology 2003, 35:526-3I.

II. Nicholls JM, Poon LL, Lee KC, Ng WF, Lai ST, Leung CY, Chu CM, Hui PK, Mak KL, Lim W, et al.: Lung pathology of fatal severe acute respiratory syndrome. Lancet 2003, 36 I: I773-8.

12. Bermejo JF, Munoz-Fernandez MA: Severe acute respiratory syndrome, a pathological immune response to the new coronavirus - implications for understanding of pathogenesis, therapy, design of vaccines, and epidemiology. Viral Immunol 2004, I 7:535-44

13. $\mathrm{Ng} \mathrm{ML}$, Tan SH, See EE, Ooi EE, Ling AE: Proliferative growth of SARS coronavirus in Vero E6 cells. J Gen Virol 2003, 84:329I-303.

14. Gu J, Gong E, Zhang B, Zheng J, Gao Z, Zhong Y, Zou W, Zhan J, Wang S, Xie Z, et al.: Multiple organ infection and the pathogenesis of SARS. J Exp Med 2005, 202:4I 5-24.

15. Ng LF, Wong M, Koh S, Ooi EE, Tang KF, Leong HN, Ling AE, Agathe LV, Tan J, Liu ET, et al:: Detection of severe acute respiratory syndrome coronavirus in blood of infected patients. J Clin Microbiol 2004, 42:347-50.

16. Peiris JS, Chu CM, Cheng VC, Chan KS, Hung IF, Poon LL, Law KI, Tang BS, Hon TY, Chan CS, et al.: Clinical progression and viral load in a community outbreak of coronavirus-associated SARS pneumonia: a prospective study. Lancet 2003, 36I:1767-72.

17. Hung IF, Cheng VC, Wu AK, Tang BS, Chan KH, Chu CM, Wong MM, Hui WT, Poon LL, Tse DM, et al.: Viral loads in clinical specimens and SARS manifestations. Emerg Infect Dis 2004, I 0: I550-7.

18. Huang KJ, Su IJ, Theron M, Wu YC, Lai SK, Liu CC, Lei HY: An interferon-gamma-related cytokine storm in SARS patients. J Med Virol 2005, 75:185-94.

19. Hsueh PR, Chen PJ, Hsiao CH, Yeh SH, Cheng WC, Wang JL, Chiang BL, Chang SC, Chang FY, Wong WW, et al.: Patient data, early SARS epidemic, Taiwan. Emerg Infect Dis 2004, I 0:489-93.

20. Wang WK, Chen SY, Liu IJ, Kao CL, Chen HL, Chiang BL, Wang JT, Sheng WH, Hsueh PR, Yang CF, et al:: Temporal relationship of viral load, ribavirin, interleukin (IL)-6, IL-8, and clinical progression in patients with severe acute respiratory syndrome. Clin Infect Dis 2004, 39:107/-5.

21. Wong CK, Lam CW, Wu AK, Ip WK, Lee NL, Chan IH, Lit LC, Hui DS, Chan $\mathrm{MH}$, Chung SS, et al.: Plasma inflammatory cytokines and chemokines in severe acute respiratory syndrome. Clin Exp Immunol 2004, I 36:95-103.

22. BGoNRPf SARS: Dynamic changes in blood cytokine levels as clinical indicators in severe acute respiratory syndrome. Chin Med J (Engl) 2003, I l 6: I283-7.

23. Xu L, Ran L, Cameron MJ, Persad D, Danesh A, Gold W, Keshavjee $S$, Brunton J, Loeb M, Kelvin DJ: Proinflammatory gene expression profiles and severity of disease course in SARS patients. International Conference on SARS, one year after the (first) outbreak; Luebeck, Germany 2004.

24. Cinatl J Jr, Hoever G, Morgenstern B, Preiser W, Vogel JU, Hofmann WK, Bauer G, Michaelis M, Rabenau HF, Doerr HW: Infection of cultured intestinal epithelial cells with severe acute respiratory syndrome coronavirus. Cell Mol Life Sci 2004, 6 I:2 100-12.

25. Ng LF, Hibberd ML, Ooi EE, Tang KF, Neo SY, Tan J, Murthy KR, Vega VB, Chia JM, Liu ET, et al.: A human in vitro model system for investigating genome-wide host responses to SARS coronavirus infection. BMC Infect Dis 2004, 4:34.

26. Tang BS, Chan KH, Cheng VC, Woo PC, Lau SK, Lam CC, Chan TL, Wu AK, Hung IF, Leung SY, et al.: Comparative host gene transcription by microarray analysis early after infection of the
Huh7 cell line by severe acute respiratory syndrome coronavirus and human coronavirus 229E. J Virol 2005, 79:6180-93.

27. Cheung CY, Poon LL, Ng IH, Luk W, Sia SF, Wu MH, Chan KH, Yuen $\mathrm{KY}$, Gordon S, Guan Y, et al.: Cytokine responses in severe acute respiratory syndrome coronavirus-infected macrophages in vitro: possible relevance to pathogenesis. J Virol 2005, 79:7819-26.

28. Reghunathan R, Jayapal M, Hsu LY, Chng HH, Tai D, Leung BP, Melen$\operatorname{dez} \mathrm{AJ}$ : Expression profile of immune response genes in patients with Severe Acute Respiratory Syndrome. BMC Immunol 2005, 6:2.

29. Law HK, Cheung CY, Ng HY, Sia SF, Chan YO, Luk W, Nicholls JM, Peiris JS, Lau YL: Chemokine upregulation in SARS coronavirus infected human monocyte derived dendritic cells. Blood 2005.

30. Hattermann K, Muller MA, Nitsche A, Wendt S, Donoso Mantke O, Niedrig M: Susceptibility of different eukaryotic cell lines to SARS-coronavirus. Arch Virol 2005.

31. Mossel EC, Huang C, Narayanan K, Makino S, Tesh RB, Peters CJ: Exogenous ACE2 expression allows refractory cell lines to support severe acute respiratory syndrome coronavirus replication. J Virol 2005, 79:3846-50.

32. Diaz MO, Ziemin S, Le Beau MM, Pitha P, Smith SD, Chilcote RR, Rowley JD: Homozygous deletion of the alpha- and beta Iinterferon genes in human leukemia and derived cell lines. Proc Natl Acad Sci USA 1988, 85:5259-63.

33. Emeny JM, Morgan MJ: Regulation of the interferon system: evidence that Vero cells have a genetic defect in interferon production. I Gen Virol 1979, 43:247-52.

34. Graham FL, Smiley J, Russell WC, Nairn R: Characteristics of a human cell line transformed by DNA from human adenovirus type 5. J Gen Virol 1977, 36:59-74.

35. Weber F, Bridgen A, Fazakerley JK, Streitenfeld H, Randall RE, Elliott RM: Bunyamwera bunyavirus nonstructural protein NSs counteracts the induction of alpha/beta interferon. J Virol 2002, 76:7949-7955.

36. Spiegel M, Pichlmair A, Martinez-Sobrido L, Cros J, Garcia-Sastre A Haller O, Weber F: Inhibition of Beta interferon induction by severe acute respiratory syndrome coronavirus suggests a two-step model for activation of interferon regulatory factor 3. J Virol 2005, 79:2079-86

37. Kotenko SV, Gallagher G, Baurin VV, Lewis-Antes A, Shen M, Shah NK, Langer JA, Sheikh F, Dickensheets H, Donnelly RP: IFN-lambdas mediate antiviral protection through a distinct class II cytokine receptor complex. Nat Immunol 2003, 4:69-77.

38. Guo J, Hui DJ, Merrick WC, Sen GC: A new pathway of translational regulation mediated by eukaryotic initiation factor 3 . Embo / 2000, 19:689|-9.

39. Collins SE, Noyce RS, Mossman KL: Innate cellular response to virus particle entry requires IRF3 but not virus replication. Virol 2004, 78: 1706-17.

40. Haller O, Kochs G: Interferon-induced Mx proteins: dynaminlike GTPases with antiviral activity. Traffic 2002, 3:710-7.

41. Garcin D, Latorre P, Kolakofsky D: Sendai virus C proteins counteract the interferon-mediated induction of an antiviral state. J Virol 1999, 73:6559-65.

42. Duan ZP, Chen Y, Zhang J, Zhao J, Lang ZW, Meng FK, Bao XL: [Clinical characteristics and mechanism of liver injury in patients with severe acute respiratory syndrome]. Zhonghua Gan Zang Bing Za Zhi 2003, I I:493-6.

43. Yilla M, Harcourt BH, Hickman CJ, McGrew M, Tamin A, Goldsmith CS, Bellini WJ, Anderson LJ: SARS-coronavirus replication in human peripheral monocytes/macrophages. Virus Res 2005, 107:93-101.

44. Zhang Y, Li J, Zhan Y, Wu L, Yu X, Zhang W, Ye L, Xu S, Sun R, Wang $Y$, et al: Analysis of serum cytokines in patients with severe acute respiratory syndrome. Infect Immun 2004, 72:44 I 0-5.

45. Lanford RE, Guerra B, Lee H, Averett DR, Pfeiffer B, Chavez D, Notvall L, Bigger C: Antiviral effect and virus-host interactions in response to alpha interferon, gamma interferon, poly(i)poly (c), tumor necrosis factor alpha, and ribavirin in hepatitis C virus subgenomic replicons. J Virol 2003, 77:1092-104.

46. Cinatl J, Morgenstern B, Bauer G, Chandra P, Rabenau H, Doerr HW Treatment of SARS with human interferons. Lancet 2003, 362:293-4. 
47. Cinatl J Jr, Michaelis M, Scholz M, Doerr HW: Role of interferons in the treatment of severe acute respiratory syndrome. Expert Opin Biol Ther 2004, 4:827-36.

48. Haagmans BL, Kuiken T, Martina BE, Fouchier RA, Rimmelzwaan GF, Van Amerongen G, Van Riel D, De Jong T, Itamura S, Chan KH, et al.: Pegylated interferon-alpha protects type I pneumocytes against SARS coronavirus infection in macaques. Nat Med 2004, 10:290-3.

49. Hensley LE, Fritz LE, Jahrling PB, Karp CL, Huggins JW, Geisbert TW: Interferon-beta Ia and SARS coronavirus replication. Emerg Infect Dis 2004, 10:3 17-9.

50. Spiegel M, Pichlmair A, Mühlberger E, Haller O, Weber F: The antiviral effect of interferon-beta against SARS-Coronavirus is not mediated by MxA. J Clinical Virol 2004, 30:2 II-2I3.

5I. Stroher U, DiCaro A, Li Y, Strong JE, Aoki F, Plummer F, Jones SM, Feldmann H: Severe acute respiratory syndrome-related coronavirus is inhibited by interferon- alpha. J Infect Dis 2004, 189: I164-7.

Publish with Bio Med Central and every scientist can read your work free of charge

"BioMed Central will be the most significant development for disseminating the results of biomedical research in our lifetime. "

Sir Paul Nurse, Cancer Research UK

Your research papers will be:

- available free of charge to the entire biomedical community

- peer reviewed and published immediately upon acceptance

- cited in PubMed and archived on PubMed Central

- yours - you keep the copyright

Submit your manuscript here:

http://www.biomedcentral.com/info/publishing_adv.asp 